DOI: https://doi.org/10.31933/dijms.v2i4

Received: 24 Febuary 2021, Revised: 7 March 2021, Publish: 12 March 2021

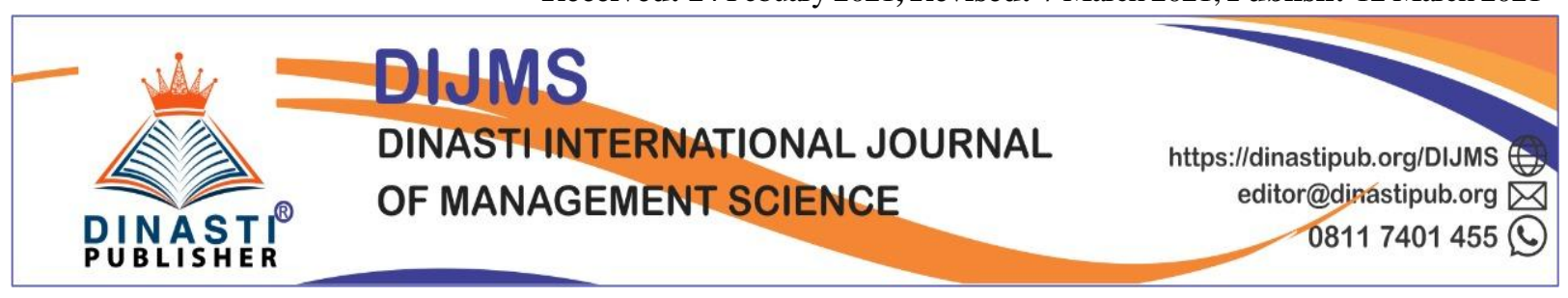

\title{
IMPROVING LECTURER PERFORMANCE THROUGH LEADERSHIP STYLE, ORGANIZATIONAL CLIMATE AND WORK MOTIVATION AT BATANGHARI UNIVERSITY, JAMBI
}

\author{
Saiyid Syekh ${ }^{1)}$, Ali Akbar ${ }^{2)}$ \\ ${ }^{1)}$ Universitas Batanghari, Jambi, Indonesia, sayid.wr1@gmail.com \\ ${ }^{2)}$ Universitas Batanghari, Jambi, Indonesia, aliakbar060873@gmail.com
}

\begin{abstract}
Abstrack: This research aims to determine Influance of leadership style, organizational climate and motivation on the performance of lecturers at Batanghari University, Jambi. The research to porpose (1) to know leadership stile, organizational climate, motivation and performance of lecturer at Batanghari University (2) to anlysis influance of leadership stile to performance of lecturer in Batanghari University (3) to analysis influance of organizational climate to performance of lecturer in Batanghari University (4) to analysis influance of motivation to performance of lecturer in Batanghari University (5) to influance of leadership style, organizational climate and motivation on the performance of lecturers at Batanghari University, Jambi. This research used survey methode with porposive sampling in 5 fakulty, with sample amounth 40 respondent. the relationship of each independent variable with the dependent variable, either individually or collectively, and makes predictions for the dependent variable on each independent variable. From the equation, it can be seen that if the leadership style can be more effective by one unit, the lecturer performance will inprove by 0.453; Likewise with the organizational climate, if the organizational climate is better by one unit, the lecturer's performance will inprove by 0.494 , something that is not much different from motivation, namely if the motivation is inprove by one unit, the performance will inprovee by 0.010 . This means that leadership style, organizational climate and motivation have a positive influance to lecturer performance. Therefore, it is expected that these three components (X1, X2 and X3) can be optimally priority to improved. The results of simultaneous hypothesis testing show that the value of $\mathrm{F}$ count is bigger than , $\mathrm{F}$ table. (Fcount $>\mathrm{F}$ table ) or sig $\mathrm{F}<0.05$, this means that simultaneously, leadership style, organizational climate and motivation have significant effect on lecturer performance at University of Batanghari Jambi.
\end{abstract}

Keywords: Leadership Style, Organizational Climate, Work Motivation, Lecturer Performance.

\section{INTRODUCTION}

A leader's success is heavily influenced by his leadership, which includes leadership and interaction skills: fellow leaders, subordinates, superiors, in-and-out organizations, and the environment. Changes in a leader greatly influence the way decisions are made and the 
performance of the organization he leads. Each leader will show his or her leadership style into certain situations, through speech, attitudes and behaviors felt by themselves and others.

Leaders in universities must be able to develop better leadership to their lecturers, in terms of wise decision making, dare to accept risks and dare to take responsibility for the decision without having to involve lecturers, so that the performance of lecturers, especially at Batanghari University can be improved.

A leader in an organization must have: Capacity. Achievements, / Responsibilities, Participation and Status (Kartono ; 2008).

Organizational climate is an internal quality of an organization experienced and felt by members of the organization. So the organizational climate is the perception of people working in the organization and its views or feelings about dimensions such as freedom, organizational structure, wages and gaki, prudence and sincerity and support for the organization (Alavi and Jahandari ; 2005; 250).

Organizational climate is an internal quality of an organization experienced and felt by members of the organization. So the organizational climate is the perception of people working in the organization and its views or feelings about dimensions such as freedom, organizational structure, wages and gaki, prudence and sincerity and support for the organization (Alavi and Jahandari ; 2005; 250).

So the organizational climate is a state or characteristic or trait that describes a psychological environment of organizations that is felt by people who are within the organization. This is if it is associated with the situation and conditions at this university, then it can be said that the organizational climate at Batanghari University on average is quite good.

To inprove the motivation of lecturers, various things are needed, among others (1) training; (2) rewarding outstanding lecturers; (3) Take an approach to optimize lecturer performance; (4) conduct special activities to build family (Pinder 2008). At Batanghari University until now relatively not oftimal done. Therefore, it takes a good effort to motivationi the lecturers so that they can work oftimally.

Judging from the performance of lecturers at Batanghari Univeristy on average is quite high, but if detailed can be divided into 2 (two) large groups, namely (1) lecturers who hold struktural positions work optimally and even feel more in all fields; so that when the time expires / replacement occurs otherwise; (2) pure lecturers who are without structural positions thank God alhamdulillah still fill absentees and carry out teaching duties even though in any way. Or in other words the performance is low. Based on this cursory observation, it is important for researchers to conduct research at Batanghari University today, because it is fully realized that the college is more focused on functional, not structural.

Judging from the performance, at Batanghari University although sluggish and not yet oftimal, but has improved. As an overview can be seen from the development of agreditation at Batanghari University such as the following table:

Table 1

Performance Accountability as seen from AME (External Quality Accreditation) for the last 5 years in Unbari Jambi

\begin{tabular}{|c|l|c|c|c|c|c|c|}
\hline \multirow{2}{*}{ No. } & \multirow{2}{*}{ AME results } & \multicolumn{6}{|c|}{ Percentage (\%) } \\
\cline { 3 - 8 } & & $\begin{array}{c}\text { Year } \\
\mathbf{2 0 1 4}\end{array}$ & $\begin{array}{c}\text { Year } \\
\mathbf{2 0 1 5}\end{array}$ & $\begin{array}{c}\text { Year } \\
\mathbf{2 0 1 6}\end{array}$ & $\begin{array}{c}\text { Year } \\
\mathbf{2 0 1 7}\end{array}$ & $\begin{array}{c}\text { Year } \\
\mathbf{2 0 1 8}\end{array}$ & $\begin{array}{c}\text { Year } \\
\mathbf{2 0 1 9}\end{array}$ \\
\hline 1. & Accreditation A & - & - & - & - & - & - \\
\hline 2. & Accreditation B & 5 & 5 & 11 & 11 & 11 & 11 \\
\hline 3. & Accreditation C & 11 & 11 & 5 & 5 & 5 & 5 \\
\hline 4. & Not yet Accreditation & 0 & 0 & 0 & 0 & 0 & 0 \\
\hline Total & & 16 & 16 & 16 & 16 & 16 & 16 \\
\hline
\end{tabular}

Source: Unbari Quality Assurance Agency 2020 
From the table above, it can be seen that until now no one has been accredited A, because it is recognized that to achieve accreditation A the requirements are very heavy, but thankfully allhamdulillah Batanghari University in 2014 as many as 5 study programs (Law, Development Economics, Management, Agribusiness and Magester Law) or by $31.25 \%$ and in 2018 rose to 11 prody (English, History, Economic Education and Cooperatives, Economic Development, Management, Agribusiness, Environmental Engineering, Agronomy, BDP and Magester Law) or $68.75 \%$.accredited B. On the contrary, the percentage of C has decreased quite drastically, namely from 11 study programs (English, History, Economic Education and Cooperatives, Bahasa Indonesia, Mathematics, Environmental Engineering, Agronomy, Lesterik, Civil Engineering, BDP and Magester Manajemen) or 68.75\% and in 2019 only 5 study programs, namely Bahasa Indonesia, Mathematics, Magester Management, Civil Engineering and Lesterik). Most of the five study programs that are still agreditation $\mathrm{C}$ are trying to reaccredit. This means that the seriousness of the leadership and staff in increasing accreditation is very high and serious or serious. Gratitude Alhamdulillah currently (Yr. 2020) two study programs namely mathematics prody and Prody Bahasa Indonesia and Magester Manajemen prosperous increase the agreditasinya to be good (B).

The benefits of this study (1) for academics. It is expected that this research can add insight into thinking in terms of leadership style, organizational climate and the motivation of lecturers' work in a private institution, where these three factors will influence a lecturer to have a good performance in providing services to the public as a whole and evenly. (2) For Batanghari University.

The author hopes that this research can provide inputs for Batanghari University in placing a leader who truly has a good leadership spirit to his lecturers.

This study is to reviwe how lecturers improve performance through leadership style, organizational climate and work motivation at Batanghari University Jambi.

\section{LITERATURE REVIEW}

According to Gomes (2003:1), management comes from the verb to manage, which means to manage, organize, implement, and manage.

Forwhile, Hasibuan (2009:1-2), stated that management is the science and art of regulating the process of utilizing human resources and other resources effectively and efficiently to achieve a certain goal.

Furthermore, according to El-qorni (2009:1) when studied management literature, it will be found that the term management contains three meanings, namely:

1. Management as a process.

2. Management as a collectivity of people who conduct management activities.

3. Management as an art and as a science.

From the above opinions and some other expert opinions, it can be summarized that Management is the overall determination and implementation of various activities, policies and programs aimed at obtaining manpower, development and maintenance in an effort to increase its support for improving the effectiveness of the organization in an ethical and accountable manner.

Leadership Style is the use of influence to motivate lecturers to achieve organizational goals. According to Aribowo (2011:20) Leadership is an affecting relationship between leaders and followers who want real change that reflects their common goals. In an effort to implement effective leadership, in addition to having the ability and skills in leadership, a leader should determine the right leadership according to the situation and conditions of group members. Or in other words Leadership style is a way for a leader to be able to work together and motivate lecturers / apparatus to realize the vision, mission, goals and objectives 
of the organization through various policies and strategies both with authoritarian and democratic and laizes priyers who are very dependent on the situation and conditions

Kartono (2008:62-63) states that a leader in an organization must have the following advantages: (1) Capacity of intelligence, vigilance, speech ability or Verbal Facilid, authenticity, ability to judge; (2) Achievements, namely science, bachelor's degrees, and others; (3) Responsibility, namely self-reliance, initiative, perseverance, tenacity, confidence, aggressiveness, and desire to excel; (4) Participation is active, has high socioability, or sociolity, cooperative or likes to work together, easily adjust, have a sense of humor; (5) The status of the socio-economic position shall be quite high, popular, calm.

According to Kahn (2006:180) that a leader does his job well if: (1) Provides satisfaction with the direct needs of his subordinates; (2) Develop a goal achievement path; (3) Eliminate obstacles to achieving goals; (4) Change the purpose of lecturers so that their objectives can be useful organizationally.

Indicators of the leadership itself according to Arep, Ishak \& Hendri Tanjung, (2002:235), among others as follows: (1) Must dare to make their own decisions firmly and appropriately (decision making); (2) Be brave to accept your own risks; (3) Must dare to accept its own responsibility (the principle of absoluteness of responsibility). In line with this, According to Thoha (2010:320-321), the leadership style in decision making, among others as follows (1) Instruction. (2) Consultation; (3) Participation; (4) Delegation.

Vardi (2001:337) defines the organizational climate as a multi-factor concept or idea that is a reflection of the organization's key functions or organizational goals, such as a conducive climate or a service climate.

Alavi and Jahandari (2005:250), demonstrating the organizational climate is the perception of the person in the organization in which it works and its views or feelings about dimensions such as freedom, organizational structure, wages and salaries, prudence and sincerity and support for the organization. In other words, the organizational climate is an internal quality of an organization experienced and felt by members of the organization.

Srivastav (2006:125), argues that organizational climate is a combination of conceptually integrated organizational karaktristics. Organizational karaktristic is described in the personality of the organization and its influence on the motivation and behavior of members in an organization. The organizational climate is the result of interactions between organizational structures, systems, cultures, leadership behavior and the psychological needs of lecturers.

Based on some of the explanations above, it can be said that the organizational climate is a state or characteristic or nature that describes a psychological environment of organizations that are felt by people who are within the organization.

Wirawan (2007:15), explained the indicators of the climate of the organization itself can be divided into:

a. Responsibility.

Responsibility is the feeling of being a leader for yourself, not always having to double-check all decisions taken, when the lecturer gets a job, the lecturer in question knows that it is his work.

b. Identity. c. Warmth.

Identity is the sense of belonging to the institution and is accepted in the group.

Warmth is a feeling of a friendly working atmosphere and is emphasized more on the condition of friendliness or friendship in informal groups, as well as good relationships between colleagues, an emphasis on the influence of friendship and informal social groups. 


\section{d. Support.}

Support is related to the support and relationships between colleagues, namely the feeling of mutual help between leaders and lecturers, emphasized on the support that needs each other between superiors and subordinates.

e. Conflict.

Conflict is a situation of conflict or dissent between subordinates and leaders and subordinates with subordinates. Emphasized on the condition that the leadership and lecturers are willing to listen to different opinions. Both sides are willing to openly address the problem and find a solution rather than avoid it.

Alavi and Jahandari (2005:250), definition the organizational climate is the perception of the person in the organization in which it works and its views or feelings about dimensions such as freedom, organizational structure, wages and salaries, prudence and sincerity and support for the organization. In other words, the organizational climate is an internal quality of an organization experienced and felt by members of the organization.

Wirawan (2007:15), explained the indicators of the climate of the organization itself can be divided into: (a) Responsibility. is the feeling of being a leader for yourself, not always having to double-check all decisions taken, when the lecturer gets a job, the lecturer in question knows that it is his work; (b) Identity is the sense of belonging to the institution and is accepted in the group; (c) Warmth is a feeling of friendly working atmosphere and is emphasized more on the condition of hospitality or friendship in informal groups, as well as good relationships between colleagues, emphasis on the influence of friendship and informal social groups; (d) Support. are matters related to support and relationships between colleagues, namely the feeling of mutual help between leaders and lecturers, emphasized more on the support that needs each other between superiors and subordinates; (e) Conflict. is a situation of conflict or dissent between subordinates and leaders and subordinates and subordinates. Emphasized on the condition that the leadership and lecturers are willing to listen to different opinions. Both sides are willing to openly address the problem and find a solution rather than avoid it.friendship and informal social groups; (d) Support.

According to Mangkunegara (2004:60), he stated that:

"Work motivation is defined as conditions which influence the arousal, direction and maintenance of behavior relevant in work setting".

(Work motivation is defined as an influential condition that evokes, directs and maintains behaviors related to the work environment).

Operationally, work motivation is an encouragement that arises from within a person to do a job in order to achieve personal and organizational goals in order to meet his/her wants or needs, both influenced by internal and external factors.

Based on the expert opinion, it can be concluded that work motivation is an encouragement that grows in a person, both from inside and outside himself to do a job with high spirit using all his abilities and skills.

Pinder (2008:2) in inproving the motivation of lecturers or lecturers, namely: Inprove the motivation of lecturers' work through training.

Sometimes pursuing the same job every day, makes most lecturers feel bored and bored. As a result, lecturers' motivation will drop so that they do not work optimally. Therefore, to restore the motivation of lecturers, you need to hold special training for lecturers. For example, conducting training to improve their work skills, or just training to rebuild the motivation of lecturers who are starting to go down.

1. Give rewards for outstanding lecturers.

It does not harm if you give special rewards for lecturers who excel. It can be a bonus or incentive, or a small gift that can represent the organization's gratitude for the 
achievements of the lecturers. This method proved to be quite effective, so that lecturers are more eager to provide further achievements for the organization.

2. Take an approach to optimize the performance of lecturers.

As a leader, you also need to approach your lecturers. If you need to recognize the advantages and disadvantages that each of them has, because this will make it easier for you to evaluate the development of each lecturer. Which lecturers have pretty good work achievements, and which lecturers need your support to achieve success like other colleagues. Of course, with this approach, you can help lecturers who have difficulty doing their duties to be able to achieve achievements like other lecturers.

3. Conduct special activities to build a family between lecturers and organizations.

Building a family between lecturers and organization leaders, becomes a surefire step to increase the motivation of lecturers' work. With a strong family, they will feel the ownership of the organization. So that his loyalty to jointly raise the organization is increasing. Hold regular meetings every month, which can familiarize all the lecturers in your organization. A warm and familiar work environment will make lecturers feel comfortable in carrying out their work.

The term performance comes from the word job performance or actual performance which means work achievement or actual achievement achieved by a person. Mangkunegara (2005:67) stated "performance is the result of work produced by a lecturer to achieve the expected goals".

According to Bernadin and Russell (2002:135) "performance is a record resulting from the function of a particular work or activity over a certain period of time".

Mathis and Jackson (2001:78), stated that "performance is basically what a lecturer does or does not do".

From the description of the definition above, it can be concluded that performance as a result of work achieved by a person or group (organization) in a certain time. In some literature, the term performance is also known as work achievement, where this work achievement is the process by which the organization evaluates the implementation of individual work. The output produced can be both physical and non-physical. To know the performance of lecturers, it is necessary to conduct an assessment of the performance itself, from the assessment it can be known whether the performance produced by lecturers has met the standards or not. By assessing the performance of lecturers, the agency can obtain information about the performance of lecturers that can be used by business entities to improve the performance of lecturers, to better motivate lecturers to want to develop themselves, as well as as the basis of planning and decision making.

Mathis and Jackson (2001:82), states; performance indicators in a lecturer, among others as follows:

1. Their abilities.

2. Motivation.

3. Support received.

4. The existence of the work they do.

5. Their relationship with the organization.

According to Wibisono (2006:186), indicators of lecturer performance in the performance management system, among others as follows:

1. Performance measurement.

2. Evaluate the measurement results.

3. Diagnosis of repair process.

4. Follow up.

Rachmawati (2007:123-125), presented the benefits that can be taken from the performance evaluation of a lecturer: 
1. Inproving achievements of lecturers.

2. Good compensation standards.

3. Placement of lecturers.

4. Training and development.

5. Career path.

6. Staff arrangement.

7. Lack of information data.

8. Design errors work.

9. Fair employment opportunities.

10. External challenges.

According to Mangkunegara (2004:70), the benefits of the lecturer's performance assessment itself, as follows:

1. Performance improvement, which is a feedback on the implementation of work allows human resources, leaders and human resources departments can correct their activities to improve performance.

2. Compensation adjustments, namely performance evaluation in terms of assisting decision makers in determining salary increases, bonuses, and other forms of compensation.

3. Placement decisions, such as promotions, transfers and usually based on past work performance or anticipation. This is because the promotion itself is often a form of appreciation for past performance.

4. Training and development needs, where poor performance may indicate the need for exercise. Likewise good performance may reflect the potential that must be developed.

5. Career planning and development, is performance feedback directing career decisions that are about a particular career path that must be researched.

6. Irregularities in the staffing process, i.e. good or poor performance reflect the strengths and weaknesses of the stuffing procedures of the human resources department.

7. Informal inaccuracies, it says, may indicate clear performance errors in the information analysis of positions, human resource plans. Relying on inaccurate information can lead to inappropriate human resource decisions.

8. Design mistakes work, here it says poor performance may be a sign of error in the design of the work. Performance assessment helps diagnose these errors.

Mangkunegara (2005:13-14) formulated factors that influence the achievement of a lecturer's performance, among others:

Human Performance $=$ Ability x Motivatio

Motivation $=$ Attitude $\mathrm{x}$ Situation

Ability $=$ Knowledge $\mathrm{x}$ Skill

Explanation:

1. Ability Factor.

Psychologically, ability consists of potential ability (IQ) and reality ability (knowledge + skill).

That is, leaders and lecturers who have an IQ above average (IQ 110 - 120) let alone superior IQ, very superior, gifted and genius with adequate education for their positions and skilled in doing daily work, it will be easier to achieve maximum performance.

2. Motivation Factor.

Motivation is defined as an attitude of leaders and lecturers towards the work situation in the organization. Those who are positive (pro) towards their work situation will show high work motivation and vice versa if they are negative (cons) to their work situation 
will show low work motivation. The working situation in question includes, among others, working relationships, work facilities, work climate, leadership policies, work leadership patterns and working conditions.

\section{Frame of Mind}

In this frame of mind includes independent variables that include Leadership Style, Organizational Climate and Work Motivation, as well as dependent variables i.e. lecturer performance, in this case the relationship between independent variables and dependent variables is described in the frame of thought as stated in the following figure:

Figure 1

Conceptual framework

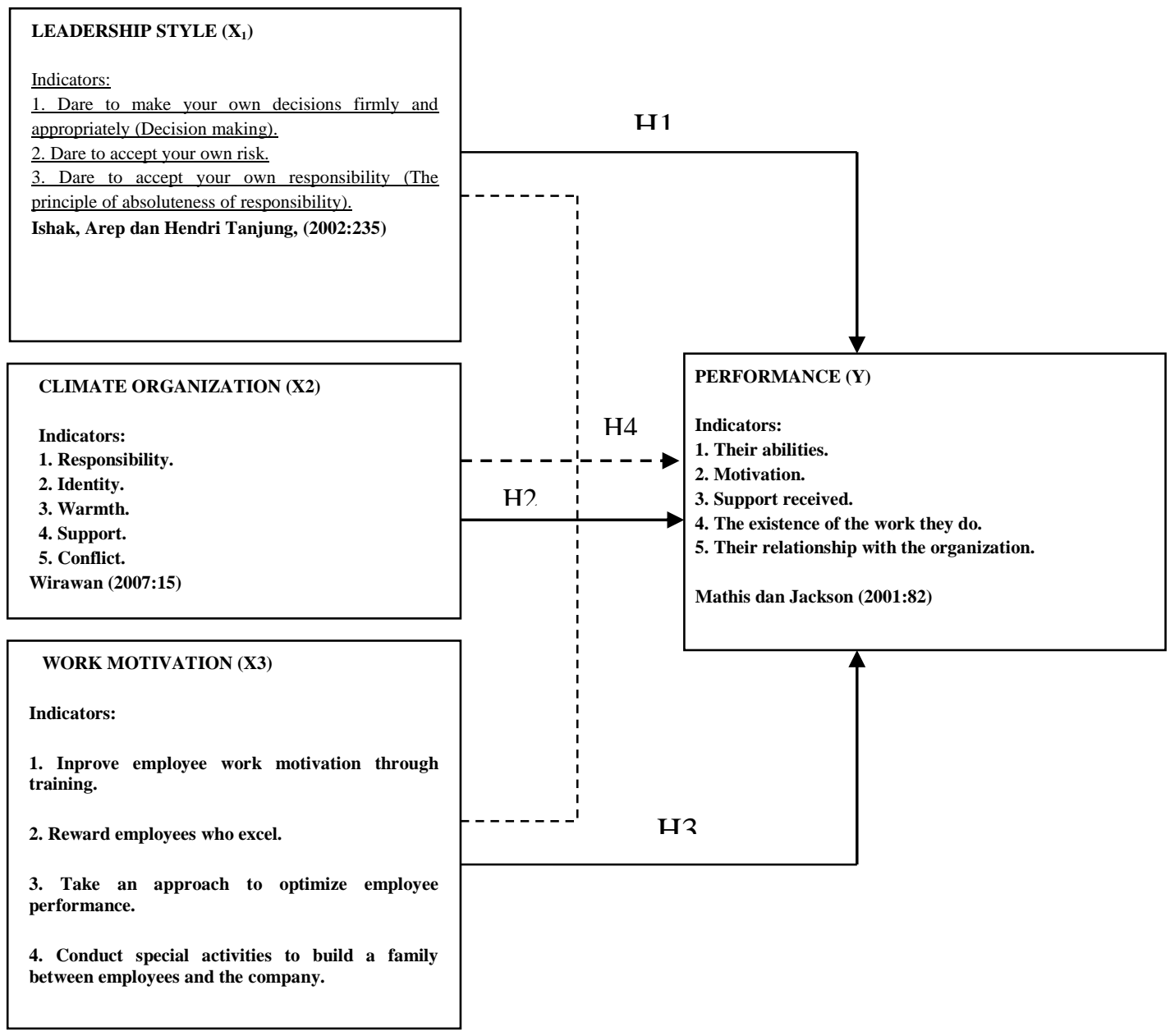

\section{Results: and Discussion}

The results of descriptive analysis of leadership style variable data that are titive using likert scale can be seen from tabulation with several sub indicators of leadership style as follows:

Table. 3

Respondents' Answers to Leadership Style Indicators

\begin{tabular}{|c|l|c|c|c|c|c|c|c|}
\hline No & \multicolumn{1}{|c|}{ Statement } & TE & KE & CE & Ef & SE & Score & \multirow{2}{*}{ Description } \\
\cline { 3 - 8 } 1. & $\begin{array}{l}\text { There is courage from the } \\
\text { leadership in every wise } \\
\text { decision. }\end{array}$ & - & 3 & 18 & 19 & - & 136 & Effective \\
\hline 2. & $\begin{array}{l}\text { The existence of careful } \\
\text { thinking in every decision. }\end{array}$ & & 1 & 12 & 23 & 4 & 150 & Effective \\
\hline 3. & There is a firm and consistent & & 1 & 13 & 24 & 2 & 147 & Effective \\
\hline
\end{tabular}




\begin{tabular}{|c|l|l|l|l|l|l|l|l|}
\hline & $\begin{array}{l}\text { attitude towards the decisions } \\
\text { that have been taken. }\end{array}$ & & & & & & & \\
\hline 4. & $\begin{array}{l}\text { There is a courageous attitude } \\
\text { in taking all the risks that have } \\
\text { occurred. }\end{array}$ & 1 & 12 & 24 & 3 & 149 & Effective \\
\hline 5 & $\begin{array}{l}\text { There is an authoritative } \\
\text { attitude and does not blame } \\
\text { others if the results of } \\
\text { decisions that have been taken } \\
\text { carry risks. }\end{array}$ & 1 & 5 & 15 & 19 & & 132 & $\begin{array}{l}\text { Effective } \\
\text { enought }\end{array}$ \\
\hline 6 & $\begin{array}{l}\text { There is a wise attitude and } \\
\text { without having to make a } \\
\text { reason that is making it up.. }\end{array}$ & 6 & 19 & 15 & & 129 & $\begin{array}{l}\text { Effective } \\
\text { enought }\end{array}$ \\
\hline \multicolumn{6}{|c|}{ Total } \\
\hline
\end{tabular}

Source: Research questionnaire 2020 (processed data)

Note: $\mathrm{TE}=$ Ineffective; $\mathrm{KE}=$ Less Effective; $\mathrm{CE}=$ Quite Effective/effective enought; $\mathrm{E}=$ Effective and $\mathrm{SE}=$ Highly Effective

From the table above, it can be seen that there is a mature mind in every decision taking the highest score, meaning that the college is very necessary careful thinking in every decision making. The next highest score is the courageous attitude in taking all the risks that have occurred. This is necessary, because if the leadership does not dare to take risks then the universities it leads are difficult to develop and progress. It means that daring to take risks must be based on careful thinking in all decision making. Followed by a firm and consistent attitude towards the decisions that have been taken.

In line with the above when associated with the hypothesis that states Leadership at Batanghari University is quite effective is acceptable. This can be seen from the average score of 140.5 which means the leadership pattern at Batanghari Effective University. Therefore, it is necessary to maintain and improve:especially:(1) mature thinking in every decision making (2) courageous attitude in taking all the risks that have occurred. (3) be firm and consistent with the decisions taken.

From the results of the recap of the answers to the items of the organization's climate sub indicators can be seen in table 4 below:

Table. 4

Respondents' Answers To The Organization's Climate Sub Indicators

\begin{tabular}{|c|l|c|c|c|c|c|c|c|}
\hline No & \multicolumn{1}{|c|}{ Statement } & TB & KB & CB & H & SB & Score & Description \\
\cline { 2 - 9 } & & $\mathbf{1}$ & $\mathbf{2}$ & $\mathbf{3}$ & $\mathbf{4}$ & $\mathbf{5}$ & & \\
\hline 2. & $\begin{array}{l}\text { There is the courage to be a leader for } \\
\text { yourself in carrying out the work }\end{array}$ & & 6 & 28 & 6 & & 120 & Good enough \\
\hline There is a high confidence in carrying & & 8 & 27 & 5 & & 117 & Good enough \\
out the work. & $\begin{array}{l}\text { There is a sense of having agencies } \\
\text { where they work. }\end{array}$ & & 5 & 17 & 18 & & 133 & Good enough \\
\hline 4. & $\begin{array}{l}\text { Acceptance from other groups in } \\
\text { carrying out their work. }\end{array}$ & & 10 & 26 & 3 & 1 & 115 & Good enough \\
\hline 5 & $\begin{array}{l}\text { There is a harmonious atmosphere when } \\
\text { working. }\end{array}$ & 1 & 7 & 22 & 10 & & 121 & Good enough \\
\hline 6 & $\begin{array}{l}\text { There is a friendly atmosphere among } \\
\text { colleagues. }\end{array}$ & 1 & 8 & 21 & 10 & & 120 & Good enough \\
\hline 7. & $\begin{array}{l}\text { There is a good relationship with } \\
\text { colleagues }\end{array}$ & & 6 & 30 & 4 & & 118 & Good enough \\
\hline 8 & $\begin{array}{l}\text { There is a good relationship with the } \\
\text { leadership }\end{array}$ & 1 & 12 & 21 & 5 & 1 & 113 & Good enough \\
\hline 9 & There is tension between colleagues. & 1 & 29 & 10 & & & 89 & Less good \\
\hline 10 & $\begin{array}{l}\text { There is un good communication with } \\
\text { the leadership. }\end{array}$ & 1 & 29 & 9 & 1 & & 90 & Less good \\
\hline
\end{tabular}




\begin{tabular}{|c|l|l|}
\hline Total & $\mathbf{1 1 3 6}$ & \\
\hline Average & $\mathbf{1 1 3 , 6}$ & Good enough \\
\hline
\end{tabular}

Source: Research questionnaire 2020 (processed data)

Note:. $\mathrm{SB}=$ Excellent $\mathrm{B}=\mathrm{Good} \mathrm{CB}=$ Good enough

$\mathrm{KB}=$ Less good TB-Not good

From the table above, it is noted that the organizational climate at Batanghari University is quite good on average. The highest score is the harmonious atmosphere when working. This is very important because if the working atmosphere is less harmonious, especially not harmonious at all will spur the difficulty to interpret and even tend to work originally, meaning that the organization will slowly or quickly be threatened with bankruptcy. So the organizational climate must be continuously improved in order for Batanghari university to develop as expected by our predecessors and now. Followed by the next highest score is the friendly atmosphere of fellow colleagues and the courage to be a leader for yourself in carrying out the work. This means that it is necessary to continuously improve the atmosphere of friendship and honesty and consistency in realizing a good organizational

From the results of descriptive analysis of motivation variable data can be seen tabulation with several sub indicators as follows:

Table. 5

Respondents' Answers to Motivational Indicators sub-Indicators

\begin{tabular}{|c|c|c|c|c|c|c|c|c|}
\hline \multirow[t]{2}{*}{ No } & \multirow[t]{2}{*}{ Statement } & SR & $\mathbf{R}$ & CT & $\mathbf{T}$ & ST & \multirow[t]{2}{*}{ Score } & \multirow[t]{2}{*}{ Description } \\
\hline & & 1 & 2 & 3 & 4 & 5 & & \\
\hline 1. & $\begin{array}{l}\text { The existence of education } \\
\text { and training carried out } \\
\text { periodically. }\end{array}$ & 1 & 2 & 26 & 10 & 1 & 128 & $\mathrm{CT} / \mathrm{S}$ \\
\hline 2. & $\begin{array}{l}\text { The sending of lecturers to } \\
\text { trainings in accordance with } \\
\text { their respective fields of } \\
\text { duty. }\end{array}$ & & 5 & 27 & 8 & & 123 & $\mathrm{CT} / \mathrm{S}$ \\
\hline 3. & $\begin{array}{l}\text { There is a direct } \\
\text { appreciation from the } \\
\text { leadership.. }\end{array}$ & & 5 & 17 & 17 & 1 & 134 & $\mathrm{CT} / \mathrm{S}$ \\
\hline 4. & $\begin{array}{l}\text { The awarding of charters } \\
\text { and award trophies }\end{array}$ & & 2 & 23 & 14 & 1 & 134 & $\mathrm{CT} / \mathrm{S}$ \\
\hline 5 & $\begin{array}{l}\text { There was a direct briefing } \\
\text { from the leadership to the } \\
\text { subordinates.. }\end{array}$ & 1 & 3 & 17 & 19 & & 134 & $\mathrm{CT} / \mathrm{S}$ \\
\hline 6 & $\begin{array}{l}\text { The existence of assistance } \\
\text { in solving problems carried } \\
\text { out by the leadership } \\
\text { directly / in person with the } \\
\text { lecturer itself. }\end{array}$ & & 3 & 23 & 13 & 1 & 131 & $\mathrm{CT} / \mathrm{S}$ \\
\hline 7 & $\begin{array}{l}\text { The existence of a joint } \\
\text { meeting forum between the } \\
\text { leadership and its } \\
\text { subordinates is held } \\
\text { regularly. }\end{array}$ & 1 & 4 & 17 & 13 & 5 & 137 & high \\
\hline 8 & $\begin{array}{l}\text { 'The existence of kinship in } \\
\text { motivating the completion of } \\
\text { work }\end{array}$ & 1 & 7 & 25 & 6 & 1 & 119 & CT/S/ \\
\hline \multicolumn{7}{|c|}{ Total } & 1040 & \\
\hline \multicolumn{7}{|c|}{ Average } & 130 & CT/S \\
\hline
\end{tabular}

Source: Research questionnaire 2020 (processed data)

Note: $\mathrm{SR}=$ very low; $; \mathrm{R}=$ low $\mathrm{CT} / \mathrm{S}=$ Quite high.medium $\mathrm{T}=$ high and $\mathrm{ST}=$ Very high 
Judging from the table above, it can be observed that only sub indicators of a joint meeting forum between the leadership and subordinates are held regularly that reach a score of 137 or highly categorized, while others are classified as quite high or moderate motivation. .Many factors that cause not high motivation, for example one of the causes is in this university research results show more on the structural approach, in fact educational institutions are usually more functional. However, the score of each sub-indikaor is quite high. This needs to be improved continuously,

Judging from the data of lecturer performance variables at Batanghari University as one of the variables measured through descriptive analysis can be described as in the following table,

Table.6

Respondents' Answers to Lecturer Performance Sub Indicators

\begin{tabular}{|c|c|c|c|c|c|c|c|c|}
\hline \multirow[t]{2}{*}{ No } & \multirow{2}{*}{ statement } & SR & $\mathbf{R}$ & CT & $\mathbf{T}$ & $\begin{array}{l}\mathbf{S} \\
\mathbf{T}\end{array}$ & \multirow[t]{2}{*}{ Score } & \multirow[t]{2}{*}{ Description } \\
\hline & & 1 & 2 & 3 & 4 & 5 & & \\
\hline 1. & $\begin{array}{l}\text { There is attention to the ability of its } \\
\text { lecturers in every job given. }\end{array}$ & & 8 & 23 & 9 & & 121 & CT \\
\hline 2. & $\begin{array}{l}\text { The provision of selection tests in each } \\
\text { placement of lecturers.. }\end{array}$ & 2 & 19 & 19 & & & 97 & $\mathrm{R}$ \\
\hline 3. & $\begin{array}{l}\text { The promotion of positions given to } \\
\text { lecturers periodically. }\end{array}$ & 2 & 16 & 21 & 1 & & 101 & $\mathrm{R}$ \\
\hline 4. & $\begin{array}{l}\text { There is direct praise by the leadership for } \\
\text { the achievements of lecturers.. }\end{array}$ & 1 & 19 & 18 & 2 & & 101 & $\mathrm{R}$ \\
\hline 5 & $\begin{array}{l}\text { There is assistance if lecturers experience } \\
\text { problems in the field. }\end{array}$ & 1 & 16 & 21 & 2 & & 104 & $\mathrm{CT}$ \\
\hline 6 & $\begin{array}{l}\text { The provision of facilities and } \\
\text { infrastructure to each lecturer in carrying } \\
\text { out work in the field. }\end{array}$ & & 15 & 22 & 3 & & 108 & CT \\
\hline 7 & $\begin{array}{l}\text { There is clarity and a complete profile } \\
\text { about the location of the work that will be } \\
\text { done by lecturers. }\end{array}$ & & 15 & 20 & 5 & & 110 & $\mathrm{CT}$ \\
\hline 8 & $\begin{array}{l}\text { There is a presentation in advance about the } \\
\text { location of the work received. }\end{array}$ & & 17 & 20 & 3 & & 106 & CT \\
\hline 9 & $\begin{array}{l}\text { The leadership gives freedom of speech to } \\
\text { each lecturer. }\end{array}$ & & 5 & 27 & 8 & & 123 & $\mathrm{CT}$ \\
\hline 10 & $\begin{array}{l}\text { The leadership always maintains good } \\
\text { communication with the lecturers. }\end{array}$ & & 13 & 27 & & & 107 & $\mathrm{CT}$ \\
\hline \multirow{2}{*}{\multicolumn{7}{|c|}{$\begin{array}{c}\text { Total } \\
\text { Sarag }\end{array}$}} & 1080 & \\
\hline & & & & & & & 108 & CT \\
\hline
\end{tabular}

Source: Research questionnaire 2020 (processed data)

Note. $\mathrm{SR}=$ Very low; $\mathrm{R}=$ Low $\mathrm{CT}=$ High enough

$\mathrm{T}=\mathrm{St}$ Height $=$ Very high

Of the ten sub-indicator items in the table above, there are 3 items that have a low categorized score and 7 items of performance sub indicators that are quite high, judging from the average score of 108 is quite high. This means that the hypothesis that states the performance of lecturers is quite high, acceptable. Dukuhat of the ten items as above, the highest value / score is the sub indicator of the leadership gives freedom of opinion to each lecturer, followed by the item to one, namely the attention to the ability of the lecturers in each given work. 
Table. 7

Influence Of Leadership Style, Organizational Climate and Motivation On the Performance of Lecturers of Batanghari University Jambi

\begin{tabular}{|c|c|c|c|c|c|}
\hline \multirow{2}{*}{ Model } & \multicolumn{2}{|l|}{ Unstandardized Coefficient } & $\begin{array}{c}\text { Standardized } \\
\text { Coefficient }\end{array}$ & $\mathrm{t}$ & Sig \\
\cline { 2 - 4 } & $\mathrm{B}$ & Stdr error & Beta & & \\
\hline Constanta & 3,120 & 2,624 & .362 & 1,105 & .277 \\
X1 &, 453 & .160 & .575 & 4,839 & .007 \\
X2 & .494 & .104 & .008 & .062 & .000 \\
X3 &, 010 & .168 & & & .951 \\
\hline
\end{tabular}

From the table above, it can be seen that X1 (leadership style) has a significant effect on performance, as well as X2 (Organizational climate) has a significant effect on the performance of lecturers. This indicates that the leadership and climate of the organization is very important and the priority to be continuously improved and prioritized with oftimal to be able to realize the maximum performance of lecturers at Batanghari University today. On the other hand, motivation shows that it has no significant effect on the performance of lecturers at Batanghari University. This shows that the motivation of lecturers at Batanghari university both from the leadership and from themselves to improve the performance of lecturers still needs to be improved so that at some point this motivation can play an important role and can even have a significant effect on the performance of lecturers, because it is important to improve the performance of lecturers in particular and the development of Batanghari University in the future generally.

In line with the above, regression equations can be created as follows;

$\mathrm{Y}=\mathrm{a}+\mathrm{b} 1 \mathrm{X} 1+\mathrm{b} 2 \mathrm{X} 2+\mathrm{b} 3 \mathrm{X} 3+\mathrm{Ei}$

$\mathrm{Y}=3,120+0.453 \mathrm{X} 1+0.494 \mathrm{X} 2+0.010 \mathrm{X} 3$

From the equation, it can be seen that if the leadership style can be more effective by one unit, then the performance of lecturers will increase by 0.453 ; similarly to the organizational climate, if the organizational climate can be improved to be better by one -unit then the performance of lecturers will increase by 0.494 , which is not much different from the motivation, namely if the motivation at the level of one unit then the performance increases by 0.010 .

Judging from the results of the F test (simultanius test) shows that leadership style, organizational climate and work motivation together have a significant effect on the performance of lecturers at The University of Batanghari Jambi The results of hypothesis testing show that the value of $F$ calculates 33.110 is greater than $F$ table 2.02439 (Fhit > Ftabel). or sig F $0.000<0.05$, this means simultaneously or jointly leadership style, organizational climate and motivation to significantly affect the performance of lecturers at Batanghari University Jambi. For more details can be seen in the following table;

Table.8

ANOVA

\begin{tabular}{|l|l|l|l|l|l|}
\hline Model & $\begin{array}{l}\text { Sum of } \\
\text { Square }\end{array}$ & df & $\begin{array}{l}\text { Mean } \\
\text { Square }\end{array}$ & F & Sig. \\
\hline Regression & 462,410 & 3 & 154,137 & 33,110 &, 000 \\
$\begin{array}{l}\text { Residual } \\
\text { total }\end{array}$ & 167,590 & 36 & 4,655 & & \\
\hline
\end{tabular}

In line with the results above, when viewed from the determination test shows that R2 of 0.734 or 73.4 percent means that 73.4 percent of lecturer performance variables are 
explained by leadership style variables, organizational climate and motivation, while the remaining 26.6 percent is explained by other variables not included in this study. This indicates that the variables are large enough to explain performance variables. For more details can be seen in the following table:

Table.9

Model Summary

\begin{tabular}{|l|l|l|l|l|}
\hline Model & R & R Square & Adjusted R & $\begin{array}{l}\text { Std. Error of } \\
\text { the Estimate }\end{array}$ \\
\hline 1 & $857^{\mathrm{a}}$ &, 734 &, 712 & 2,158 \\
\hline
\end{tabular}

\section{DISCUSSION}

In the lead, careful thinking in every decision is made. It is necessary that it is very reasonable that the results of this study show that there is a mature thought in every ppengambilan nebempati desperation of the highest value, kenudian followed by the nature of the existence of a courageous attitude in bearing all the risks that have occurred., this means that a leader who suskses must be brave and responsible. At Batanghari University Jambi the leader can be categorized as brave and responsible

One of the factors causing unbari's progress is the presence of a sense of having, so that the organizational climate is not yet fully in accordance with expectations but is quite conducive.

Judging from the average motivation is not yet high, this is especially in Unbari is more likely to be on a structural approach, so that lecturers who are not included in the structural motivation can be categorized as low to very low, this Penomena gradually should be dirobah if the university is going forward. Conto from various motivational indicators, only the existence of a joint meeting forum between the leadership and his subordinates are held regularly. High bermi;ai. This further reinforces the noting that at the University it is more likely to be structural. Walhal College that amju is more inclined to functional. Due to the motivation that has not been high, the performance of lecturers is also relatively notyet high.

The results of the $\mathrm{F}$ test showed that together the pattern of leadership, organizational climate and motivation significantly influenced to performance $(\mathrm{Y})$. This means that these three kmponents must obtain a priority to be intensified and improved.

The results showed that the $t$ ttest (partial test) leadership had a significant influence on $Y$ (performance), this was nerearti leadership in the prosin. The organization's climate also have sinikantly influance to performance (Y) this is in line with the results of the research of constituents in Tanjung Jabung Timur Regency.. But unfortunately at Batang hari University on Jambi day the motivation did not significant influence on the prtformance (Y). This is mainly due to weak material and inmaterial impulses that are relatively low.the material and supritual impulses.

\section{CONCLUSIONS}

Leadership style, and organizational climate, are quite good, work motivation and lecturer performance is quite high at Batanghari University Jambi. The results showed that the deriftive hypothesis that states the leadership style, and organizational climate, is quite good, work motivation and lecturer performance is quite high at Batanghari Jambi University can be accepted. His leadership style has a significant influence on the performance of lecturers at Batanghari University Jambi. This is indicated by the results of thitung >ttabel then it can be concluded that $\mathrm{Ha}$ accepted Ho rejected means X Leadership style has a significant effect on performance. Lecturer at Batanghari University Jambi. 


\section{Recommendations}

1. It is expected that individual lecturers to continue to improve their performance will certainly realize the moral and material motivation of the external and internal leadership elements of this University;

2. Intensifying Leadership style, Organizational Climate and Motivation to improve the performance of lecturers both in the field of education and teaching as well as in the field of research and community service needs to be continuously improved.

\section{LITERATURE CITED}

Arikunto, Suharsimi. 2007. "Research Procedure a Practical Approach, Revised Edition". Rineka Cipta : Jakarta.

Alavi, Hamid Reza and Ramazan Jahandari. 2005. "The Organizational Climate Of Kerman Shahid Bahonar University", Journal Public Personnel Management.

Arep, Iskhak \& Hendri Tanjung, 2002. "Variables, Dimensions and Leadership Indicators". Source:http://metodologi-penelitian.blogspot.com/2011/01/variabel-dimensi-danindikator.html.

Aribowo, Risky. N. (2011). Thesis. "The Influence of Leadership, Motivation and Physical Work Environment on Employee Performance (Study On CV. The work of Mina Putra Rembang Wood Division)". Faculty of Economics, Diponegoro University. Semarang.

Bernadin \& Russell. 2002."Fundamental Organization Behavior", Translated by Agus Dharma. Publisher : Erlangga, Jakarta.

Elfrida, Dame. (2009). Thesis. "Analysis of Organizational Climate Influence, Motivation and Compensation on The Spirit of Work of Correctional Institution Officers Klas-II B Lubuk Pakam". USU Repository (C) 2009.

El-qorni. 2009. Learning Modules. "Definition and Functions of Management". Source : http://elqorni.wordpress.com/2009/03/15/pengertian-manajemen-dan-fungsifungsinya-definition-and-functions-of-management/. (Accessed March 19，2011, 5:30:14 PM)

Gomes, F.C. 2003. Human Resource Management. Publisher : ANDI, Yogyakarta.

Gustiyah, Raika. (2009). Thesis. "Analysis of Factors That Affect The Work Motivation of Industrial Extension Workers at the Office of the Office of Revenue and Trade of the City of Medan". USU Repository (C) 2008.

Hasan, M. Iqbal. 2001. "The Subject matter of Statistical Material I (descriptive statistics) ; Second Edition". Bumi Aksara : Jakarta.

Hasibuan, M. S. P. 2009. "Human Resource Management" Revised Edition. Publisher : Bumi Aksara, Jakarta.

Hasnita, E \& Rossi S. (2006). Working Paper Series No. 1 April 2006. "Characteristics, Organizational Climate, and Performance of Nurses In Hospital Inpatient Installations. Dr. Achmad Moechtar Bukittinggi Year 2005". UGM, Yogyakarta.

Haryanti, Endang. (2005). Thesis. "Analysis of the Influence of Leadership Style and Organizational Climate on Job Satisfaction and Employee Performance of Gayamsari Sub-District Office of Semarang City Government". Faculty of Economics, Diponegoro University. Semarang.

Idrus, M. (2006). Journal. "Organizational Climate Implications for Job Satisfaction and 
Quality of Lecturer's Work Life". Diponegoro University.

Kahn, R.L. 2006. "Human Relation on The Shop Floor". Quoted by O. Jeff Harris, Jr. "Managing People of 70 Work". John Willrey \& Gons, Inc-Press.

Kartono, Kartini. 2008. "Organization, Leadership and Administrative Behavior". Publisher : CV. Hajj Masagung. Jakarta.

Mangkunegara, A.A. Prabu. 2004. Human Resource Management. Publisher : Remaja Rosdakarya, Bandung.

Mangkunegara, A.A. Anwar Prabu. 2005. "Hr Performance Evaluation". Publisher : PT. Refika Aditama, Bandung.

Mathis, Robert L. \& John H. Jackson. 2001. "Performance". Wikipedia source. http://id.wikipedia.org/wiki/Kinerja.

Research (SPSS Program Application Equipped)". Publisher : Pustaka Setia, Bandung.

Nototmodjo, Soekidjo. 2009. Human Resource Development. Publisher : Rineka Cipta, Jakarta.

Pinder, what's going on? 2008. "Understanding Motivation". SourcHttp://bisnisukm.com/carameningkatkan-motivasi-kerja-pegawai.html

Rachmawati, Ike K. 2007. Human Resource Management. Publisher : Andi, Yogyakarta.

Sedarmayanti. 2010. "Human Resource Management: Bureaucratic Reform and Civil Servant Management". Publisher : PT. Refika Aditama, Bandung.

Siagian, Sondang. P. 2009. "Tips to Increase Work Productivity". Publisher PT. Rineka Cipta. Jakarta.

Srivastav, Avinash Kumar,2006, "Organizational Climate as a Dependent Variable, relationship with role stress, coping strategy and personal variables", Journal Of Management Research, Vol.6, No.3, Dec.

Toha, Miftah. 2010. "Organizational Behavior: Basic Concepts and Applications". Publisher : PT. King Grafindo Persada. Jakarta.

Vardi, Yoav. 2001. "The effects of organizational and ethical climate on misconduct at Work". Journal of Business Ethics.29: 325-337

Wibisono,H. D. 2006. "Performance Management: Concepts, Designs, and Techniques to Improve The Company's Competitiveness". Publisher : Erlangga, Jakarta.

Wirawan. 2007. "Cultural and Climate Organization". Publisher : Salemba Empat, Jakarta.

Zuryati, what's going on? 2005. "Statistical Research Method". Publisher : Remaja Rosda Karya, Bandung. 